\title{
SUSTAINABILITY, TERRITORIAL RESOURCES AND SOCIAL CAPITAL
}

\author{
T. CILONA \\ Department of Architecture, University of Palermo, Italy.
}

\begin{abstract}
In Italy, in the last two decades, new methods of intervention in planning and land policies have been used, which focused more and more on territorial government, governance, development, cohesion and environmental sustainability. One of the main factors that has contributed to the dissatisfaction of the residents is the lack of quality in the towns, which has been more and more characterized by urban decay and by lack of services and gathering places. Giving back environmental, economic and social quality to degraded areas or recovering abandoned public spaces responds definitely to the concept of sustainable city limiting urban sprawl and reducing environmental impacts inherent in the built environment. Moreover, soil consumption in also related to the economics involved, in other words what we commonly call cost to the environment, which cannot be underestimated if the perspective with which we work is that of improving sustainability. In this overview, new forms of cooperation between citizens and public authorities for the care and regeneration of the commons goods is essential. Citizen participation is certainly an important element to develop and to support sustainable policies. The contribution of a multidisciplinary approach, highlights interventions of urban regeneration and models of participated urban planning realized in some Sicilian towns in recent years. Through a participated management, a socio-economic integration of technology and culture has been undertaken thanks to the aesthetic functional and technological restoration of the places.
\end{abstract}

Keywords: place-identity, sustainability, urban renewals.

\section{INTRODUCTION}

The development of a community is accomplished by achieving human needs, fulfilling the aspirations of the community and by following a process of transformation that will improve the living conditions in different areas, namely, health care, education, residence and other essential services essential. However, a brief explanation is necessary. After the industrial revolution and the world wars, economic growth and technological development have led to substantial changes in the quality of life, especially in Western countries, where it has improved a lot.

However, in recent decades, the global community has reached a development that cannot be said to be sustainable.

Today, the world is facing a deep crisis, and in different sectors:

1. Environmental crisis (global warming, deforestation, loss of biodiversity, climate change, greenhouse gas emissions, waste management, renewable energy, depletion of natural resources, food security, water conservation, infrastructure management);

2. Economic crisis (poverty, financial inequality, unemployment, social safety nets); 
3. Social Crisis (human rights, socio-cultural, religious, racial, social exclusion, discrimination, illiteracy);

4. Global Crisis (equitable distribution of resources, unemployment, technological, migration, terrorism);

5. Crisis in Governance (efficiency of territorial and human resources, staff welfare, working conditions and safety measures, best practices in management, unhealthy competition practices);

6. Crisis of public management (human, natural, financial, social, participatory management), [1].

In this regard, in fact, in order to avoid further damage, it is necessary to reverse the system that brought about the socio-economic imbalances and environmental degradation, as well as enable sustainable initiatives at all levels: international, national, regional, local and individual.

\section{SUSTAINABLE DEVELOPMENT OF CITIES}

In Italy, as in many countries of the European community, the territorial system has become increasingly important in economic development policies.

In recent years, it has triggered an interesting interdisciplinary debate where the territory is seen as the key to allowing one to decipher the conditions in which local companies help to resolve the crisis caused by economic globalization, cultural and political characterize the contemporary.

Thus, in the various disciplines, the geography of the economy, from architecture to urban planning, from social sciences to biological, anthropological and political, the territory and the quality of space are seen as strategic resources for development.

\subsection{Land resources, economic development policies}

The attractiveness of urban systems is closely linked to the quality of living as well as the charm of the place. Central themes are in fact those of the urban welfare and the organization of services and, in particular, the conditions of sustainability and security, which are real challenges towards making a city liveable in the twenty-first century. Cities are strained by increasingly marked processes of environmental pollution, dislocation of social structures, environmental degradation, climate change, depletion of conventional energy sources and disintegration of social cohesion. To better fight the environmental risks, the prospect of sustainable cities is spreading everywhere [2].

But what is it meant by sustainable development?

According to the Brundtland Report of 1987, also known as Our Common Future, a document issued by the World Commission on Environment and Development (WCED) [3] - the concept of sustainable development is defined for the first time as the necessity to satisfy the present needs without compromising the ability of future generations to meet their own needs. Following the Brundtland Report, more definitions about the concept of sustainable development have been provided, which state that human well-being, health, wealth and quality of life of the people are related to the diversity, productivity and quality of the ecosystem. Therefore, sustainability has to improve to maintain the well-being of people and the ecosystem together. The well-being of one is linked to the welfare of the other. It follows that sustainable development implies improving and maintaining the health of both [4]. 


\subsubsection{Human capital}

For the multiplicity of problems that sustainable development faces, the participation and contribution of human capital, that is, of people able to use their knowledge to achieve economic prosperity, social and environmental equity is essential. What in technical terms is called triple bottom-line: quality, training and education of human capital, which are primarily responsible for the transformation of resources, for the improvement of the economy, to promote and support innovation and to adopt appropriate technologies for development. From here it follows that education is the tool for training human resources to optimize productivity by encouraging technical progress and by promoting cultural conditions conducive to social and economic change $[5,6]$. In fact, the concept of human capital was developed in 1960 by a group of economists and the idea that investment in education generates economic and social benefit for the individual and society in general, dates back to 1776 with Adam Smith's theoretical macroeconomics, that evinced interest in the forces that determine economic growth. Over the years, several researchers have attempted to define the concept of human capital with simplicity and clarity, demonstrating that physical capital alone is not sufficient to encourage long-term development [7, 8]. Many economists argue that human capital is the most important factor that determines the development and, that absence of human capital would be completely useless. No country, in fact, may think of economic progress without striving to increase the knowledge, skills and abilities of its citizens to manage the available resources. Human capital is the most valuable asset of any nation. That is why sustainable development is essential to its formation - skills and abilities acquired by individuals, groups and associations to enable them to carry out assigned responsibilities to achieve the objectives - in order to avoid undesirable consequences to the environment $[9,10]$.

\subsubsection{Social capital}

In urban and regional studies, human capital should be flanked by joint stock, a complex concept, for which we try to define a meaning.

The word "capital" refers to the idea of wealth and abundance, while "social" intuitively qualifies it as something positive for everyone and, therefore, for a collective good [11]. Or, we can say that the joint capital is the relationship between the network of social relations and all the various kinds of resources $[12,13]$, a combination of structural and regulatory elements of the social structure that encourages collective action or cooperation between individuals within a group or a community $[14,15]$.

It is in relation to the social, institutional and cultural dimensions that the joint stock comes into play as a key requirement for sustainable development. The collective regulation requirements, regeneration of resources, reproduction of the social relations, the growth of knowledge and skill spread, bring into common connection and heritage institutions, the joint capital and governance dynamics (meaning the increasing ability over time to design, plan, manage and evaluate, to exploit potential and capacity for innovation and to strengthen networking and political leadership) [16, 17].

The joint capital can be seen as a set of social assets that produce a certain amount of public benefits and, therefore, development [18].

It has been widely demonstrated by the European Union, with the Urban I (1994-1999) and Urban II (2000-2006) programs, that the city underwent urban regeneration interventions, including both material and social transformations, which have reactivated feelings of confidence for the possibility of collective redemption local, Fig. 1, [19, 20]. 


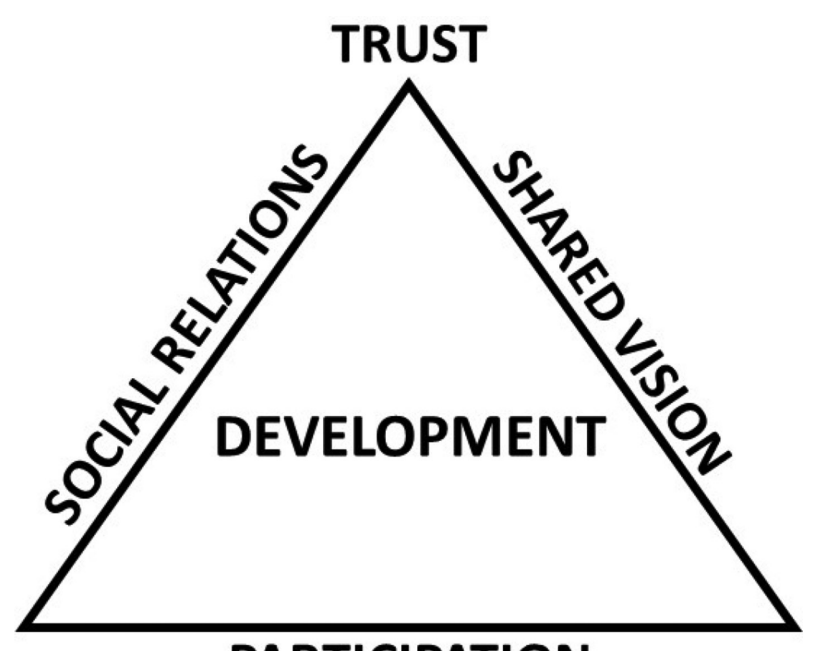

\section{PARTICIPATION}

Figure 1: The social capital as a factor for local development.

\section{URBAN TRANSFORMATION}

The European political programming 2014-2020, has as its purpose the implementation of the Europe 2020 Strategy.

The objective is to overcome the crisis, fill in the gaps of the growth pattern and create conditions that are more intelligent, sustainable and inclusive (Table 1).

The Sicilian cities, are incredibly late in the application of strategic planning and the principles of sustainable development, Fig. 2.

Only a few have joined the Aalborg Charter [21, 22], and implemented projects following the directions of the Local Agenda 21. In fact, the transition from government to governance, which is useful to guarantee more and better conditions of governance in the island city, has many problems [23]. Table 2 indicates the strengths and weaknesses as well as the opportunities and the risks present in the Sicilian territory [24].

Among the causes, it is increasingly difficult to manage the urban areas, where the relationships between economic, social and cultural reasons, are becoming increasingly complex.

In this scenario, the urban and territorial transformation must follow the principles of a participatory and shared vision, thanks to the active collaboration of public and private institutions.

This is to address the increasing complexity of the decisions concerning the city, through new forms of transparency and democracy [25].

\subsection{Land management policies}

After decades of failure in land management policies, it is observed that partnership with the community is essential in order to enable citizens to take an active part in the formulation of public policies - especially in those urban - being also the only recipients. Participatory practices are of various kinds and correct identification allows citizens to acquire maximum information and awareness, Fig. 3, also provides tools - in different times and ways by the classic expression of the vote - that enable it to deliver, work judgments consensus, dissent, or the proposition of alternative solutions to diverse problems [26]. 
Table 1: Europe 2020 Strategy - Sustainable cities.

\begin{tabular}{|c|c|c|c|}
\hline Social Development & $\begin{array}{c}\text { Economic } \\
\text { Development }\end{array}$ & $\begin{array}{l}\text { Enviromental } \\
\text { Development }\end{array}$ & Urban Governance \\
\hline Education and health & $\begin{array}{l}\text { Green productive } \\
\text { growth }\end{array}$ & $\begin{array}{l}\text { Forest and soil } \\
\text { management }\end{array}$ & $\begin{array}{l}\text { Planning and } \\
\text { decentralization }\end{array}$ \\
\hline Food and nutrition & $\begin{array}{l}\text { Creation of the } \\
\text { employment }\end{array}$ & $\begin{array}{l}\text { Waste and recycling } \\
\text { management }\end{array}$ & $\begin{array}{l}\text { Reduction of } \\
\text { inequities }\end{array}$ \\
\hline $\begin{array}{l}\text { Green housing and } \\
\text { building }\end{array}$ & $\begin{array}{l}\text { Production and } \\
\text { distribution of } \\
\text { renewable energy }\end{array}$ & Energy efficiency & $\begin{array}{l}\text { Strengthening of civil } \\
\text { and political rights }\end{array}$ \\
\hline Water and sanitation & $\begin{array}{l}\text { Technology and } \\
\text { innovation }\end{array}$ & Water management & $\begin{array}{l}\text { Local, national, } \\
\text { regional and global } \\
\text { links }\end{array}$ \\
\hline $\begin{array}{l}\text { Green, public } \\
\text { transportation }\end{array}$ & & $\begin{array}{l}\text { Air quality } \\
\text { conservation }\end{array}$ & \\
\hline Green energy & & $\begin{array}{l}\text { Mitigation of climate } \\
\text { change }\end{array}$ & \\
\hline $\begin{array}{l}\text { Recreation areas and } \\
\text { community support }\end{array}$ & & & \\
\hline
\end{tabular}

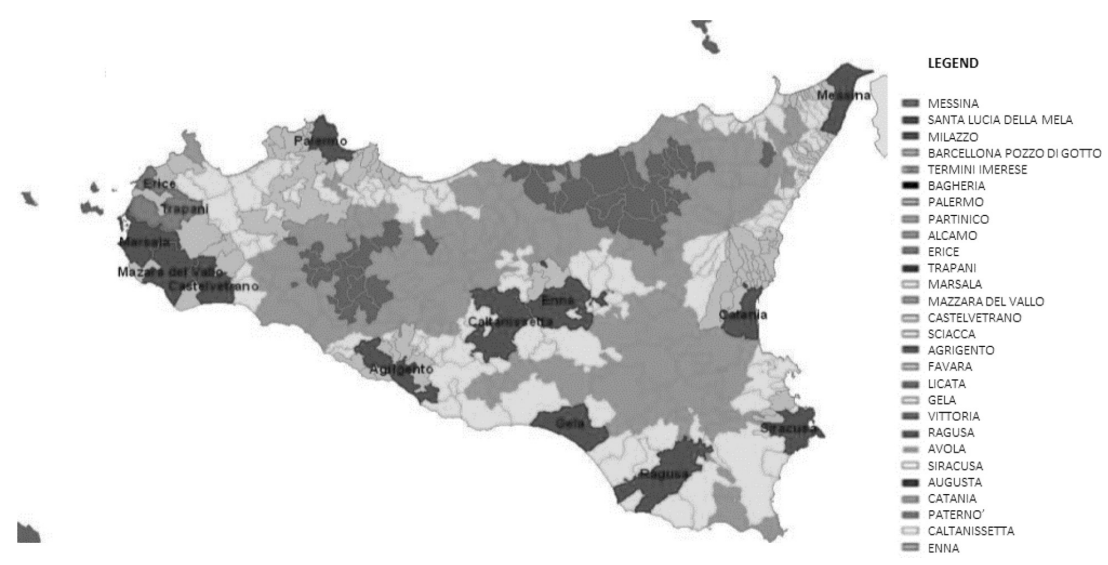

Figure 2: Sicily - map of strategic plans.

3.1.1 Redevelopment and economic planning

By some data from the Regional Infrastructure of 2015, in about 40 municipalities of the Region, more than 60 million euro for urban redevelopment will be invested in the coming years. These are funds from Asse 6 P.O. FERS, Operational Programme of the European Regional Development Fund [27, 28]. 
Table 2: Sicilia 2014-2020, sustainable development, strengths and weaknesses and opportunity and risks.

\begin{tabular}{|c|c|}
\hline \multicolumn{2}{|c|}{ Sustainable Development } \\
\hline Strengths & Weaknesses \\
\hline Infrastructure & Deficiency of infrastructure \\
\hline Urban development planning & Failed urban development planning \\
\hline Old town centre & Decay of old town centre \\
\hline Sustainable urban transport & Insufficient sustainable urban transport \\
\hline Tourist attraction & Insufficient development of heritage \\
\hline Renewable energy & Insufficient use of renewable energy \\
\hline $\begin{array}{l}\text { Resources - cultural, historical, } \\
\text { archaeological, natural }\end{array}$ & $\begin{array}{l}\text { Inadequate development of resource } \\
\text { management policies }\end{array}$ \\
\hline Opportunity & Threats and Risks \\
\hline $\begin{array}{l}\text { European programmes POR, PON, } \\
\text { APQ, CIS }\end{array}$ & Abandonment of marginal areas \\
\hline Increase in trade flows & Destruction of natural habitats \\
\hline Technology development & Deterioration - degeneration \\
\hline Planning strategies & Risk hydrogeological, desertification, pollution \\
\hline
\end{tabular}
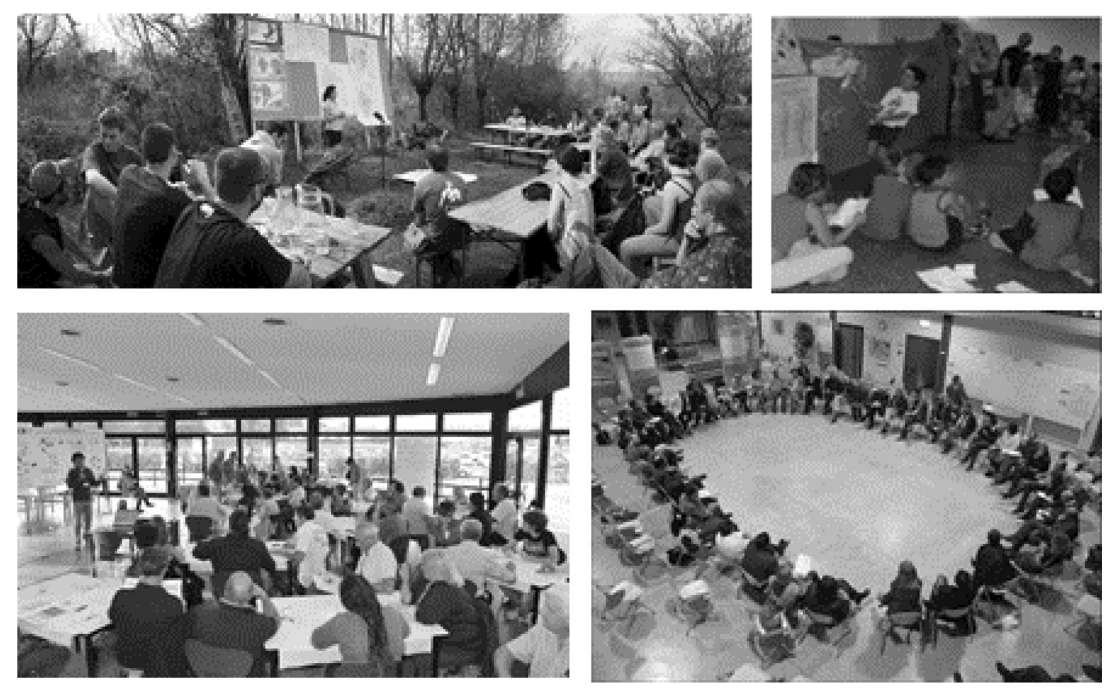

Figure 3: Examples of participatory practices. 
Specifically, they were funded for urban regeneration interventions in municipalities of more than 30,000 inhabitants, among these are:

1. Catania, with the new functions of the historical building called Chinese Kiosk at the Garden Bellini, amounting to over EUR 7 million, Fig. 4, [29];

2. Messina, with the construction of a ground level car park 'Torre Faro', amounting to more than EUR 4 million, Fig. 5, [30].

3. Barcellona Pozzo di Gotto, with interventions on roads, renovation of existing sidewalks, parking amounting to EUR 3 million and a half or so, Fig. 6, [31].

While among the municipalities with a population of less than 30,000 inhabitants, there are:

1. San Giovanni La Punta, (in the province of Catania), for the construction of a service centre in the industrial area with contributions amounting to approximately EUR 2 million, Fig. 7, [32].

2. Valderice EUR 3,200,000 to complete sports facility in Misericordia district, Fig. 8, [33].

3. The town of Maletto, (in the province of Catania) for the completion of the day centre for the elderly, with contributions amounting to about EUR 1,150,000, Fig. 9, [34].

4. The town of Mazzarino, the restoration of Palazzo Bartoli, with contributions amounting to EUR 1,200,000, Fig. 10, [35].
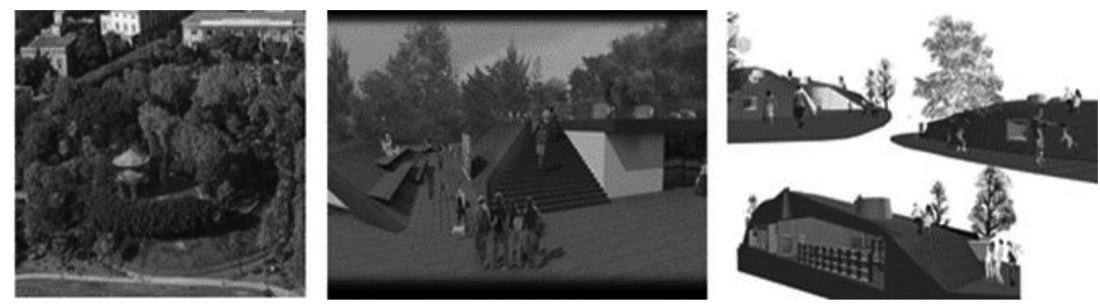

Figure 4: Catania - Garden Bellini - Urban redevelopment.
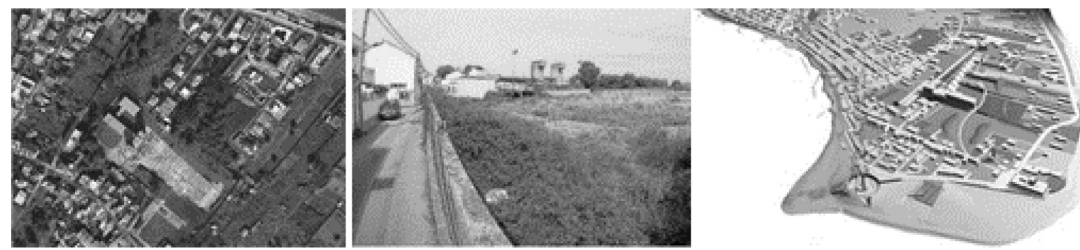

Figure 5: Messina, Torre Faro, realization of a parking.
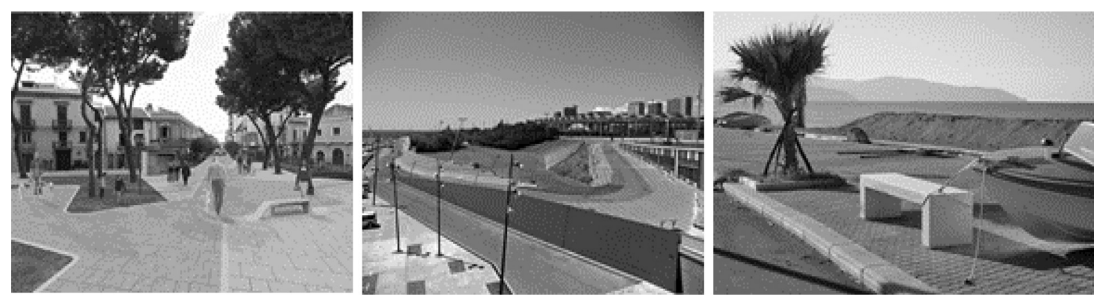

Figure 6: Barcellona Pozzo di Gotto, urban redevelopment. 

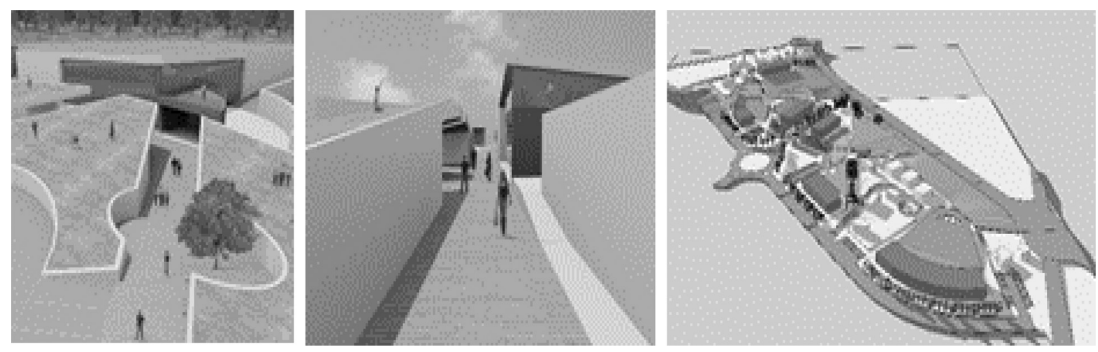

Figure 7: San Giovanni La Punta (Catania), construction of a service centre.
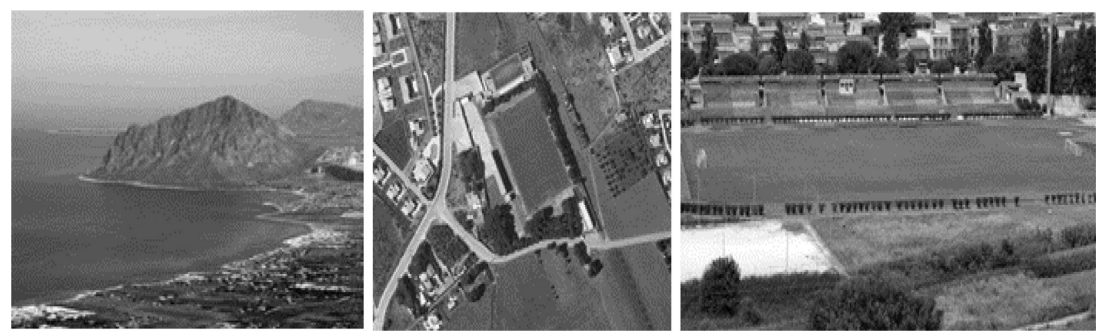

Figure 8: Valderice, redevelopment intervention of sports facility.
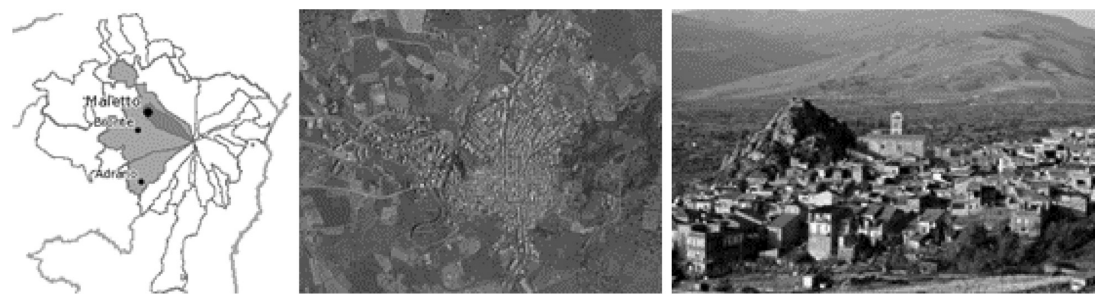

Figure 9: Comune di Maletto (Catania), urban redevelopment.
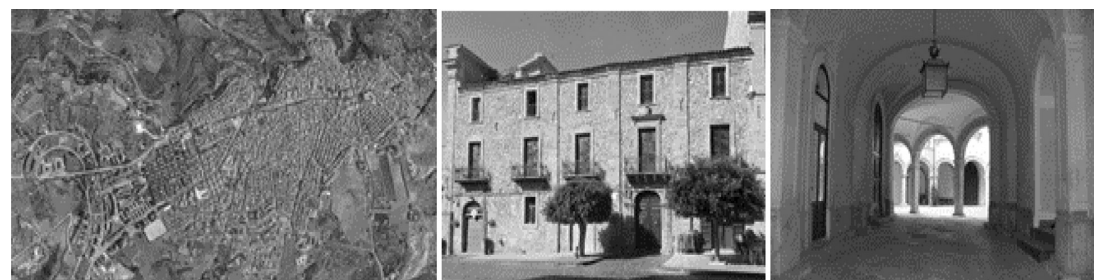

Figura 10: Mazzarino (Caltanissetta), Bartoli building, restoration work.

\section{CONCLUSIONS}

The gradual phenomenon of human settlement of the area began with the industrial revolution of the late nineteenth century, followed by the so-called "boom" of the 1960s and continued well into the last century, leading to the gradual abandonment of agricultural land and producing significant changes to the landscape.

These changes, due to a significant increase in the population, the change in its position on the territory resulting from a significant increase in overall urbanization and infrastructure in 
general, have resulted in a widespread degradation on existing agricultural landscapes, both from the qualitative and quantitative point of view. In fact, there has been an increasing use of agricultural land for different uses - residential, industrial, tertiary - with a subsequent loss of productive soil.

Thus, urban sprawl has replaced the centripetal one of the 1960s-1980s leading to a gradual abandonment of the inland land, the hill and mountain systems with the consequent expansion of settlements that, in a few decades, have developed in an uncontrolled way and, in some cases, disproportionately, partly because of the bankruptcy of a land management policy, as well as due to personal interests and private enterprises. Today, cities are complex and dynamic realities and the choices to be taken to ensure the welfare of citizens and to satisfy the needs of the community depend on the availability of resources, the company's assets and financial availability.

The challenge is to provide services and equipment suitable to the inhabitants, manage migration flows to address climate change, to secure a job and reduce poverty. The participation of the inhabitants is, therefore, an opportunity to improve the qualitative aspects of a project that focus on their real needs. It guarantees the effectiveness of the project itself and provides credibility to a little appropriate land management process to the complex society of today.

\section{REFERENCES}

[1] Miller, J. \& Tyler, J., Living in the Environment, 8th edn., Wadsworth Publishing Company: Belmont, California, 1994.

[2] Clementi, A., Territorio: una risorsa per lo sviluppo - XXI Secolo, 2010.

[3] World Commission on Environment and Development, (WCED), Our Common Future, Rapporto Brundtland, Oxford University Press: Oxford, UK, 1987.

[4] Sampson, E., Sustainable development: issues, strategies and goals. Zenith Economic Quarterly, 7(2), 2013.

[5] Becker, G., Human Capital, Columbia University Press: New York, 1964.

[6] Melnychuk, D.O., Pidlisnyuk, V. \& Stefanovska, T.R., Key Questions About Sustainable Development: What Everyone Needs to Know,Hopak Publisher House: Kyiv, 2010.

[7] Mimiko, F., Human Capital Development Blueprint: a pragmatic approach to resolving the challenge of capacity gaps in organizations in Nigeria. Paper delivered at the Ondo State Ministry of economic Planning and Budget Year Quaterly Lecture, November 22, 2012.

[8] Gough, S. \& Scott, W., Education and sustainable development: a political analysis. Educational Review, 58, 2006.

[9] Hardi, P. \& Zdan, T. (eds.), Assessing Sustainable Development, Canada, 1997.

[10] Kates, R.W., Parris, T.M. \& Leiserowitz, A.A., What is sustainable development? goals, indicators, values and practice. Environment Science and Policy for Sustainable Development. 47(3), pp. 8-21, 2003.

[11] Putnam, R.D., Capitale sociale e individualismo. Crisi e crescita della cultura civica in America, ed. Il Mulino Saggi, 1993.

[12] Sabatini, F., Che cosa è il Capitale Sociale? Dis/Uguaglianze, Trimestrale per l'analisi dei processi di sviluppo e sottosviluppo, 3, pp. 41-55, 2004.

[13] Coleman, J.S., Social capital in the creation of human capital. American Journal of Sociology, 94, 1998.

[14] Portes, A., Social capital: its origins and applications in modern sociology. Annual Review of Sociology, 24, pp. 1-24, 1998.

http://dx.doi.org/10.1146/annurev.soc.24.1.1 
[15] Coleman, J., Foundations of Social Theory, Harvard University Press: Cambridge, 1990.

[16] Field, J., Social Capital, Routledge: London, 2003.

[17] Putnam, R.D., Social capital and individualism. Crisis and Development of the Learning, ed. Il Mulino Saggi, 2000.

[18] Trigilia C., Capitale sociale e sviluppo locale. In Bagnasco, Piselli, Pizzorno, Trigilia, Capitale sociale: istruzioni per l'uso, Bologna, Il Mulino, 2002.

[19] Ministero delle Infrastrutture e dei Trasporti (MIT), Programmi Urban I, Urban II e Urban Italia, Rete delle Città Urban Italia, 2003/2008.

[20] Lopolito, A. \& Sisto, R., Il Capitale Sociale come fattore di sviluppo locale. Aspetti teorici ed applicativi Quaderno n. 07/2007.

[21] Aalborg Charter - Carta delle città europee per uno sviluppo durevole e sostenibile (Aalborg - Danimarca, 27 maggio 1994), available at: http://www.minambiente.it/normative/carta-di-aalborg-carta-delle-citta europee-uno-sviluppo-durevole-e-sostenibilealborg\#sthash.J9BZmnim.dpuf

[22] Agenda 21, documento delle Nazioni Unite su Ambiente e Sviluppo (UNCED), Rio de Janeiro, giugno 1992, available at: http://www.minambiente.it/pagina/cose-lagenda21\#sthash.olNBQnEg.dpuf.

[23] Ruggiero L., ERSA 2003 CONGRESS University of Catania Italy - Governance urbana e sviluppo sostenibile in Sicilia, 2003.

[24] PO FESR Sicilia 2014-2020, Allegato 1 Analisi Swot.

[25] Cilona, T., Sviluppo delle città. Action planning e processi partecipativi, 1, pp. 1-60, Agrigento, CEPASA Editore, 2013.

[26] Cilona, T., Villaseta: Open city action planning, il caso studio di un quartiere a sudovest di Agrigento. introduzione alla tesi di laurea di Tiziana Petrotto, a.a. 2012/2013, Università degli studi di Palermo, corso di studio in Architettura di Agrigento, 2013.

[27] FERS, Fondo Europeo Regionale, Commissione Europea, politica regionale, available at: http://ec.europa.eu/regional_policy/index.cfm/it/funding/erdf/

[28] Po Fesr Sicilia 2014-2020, Allegato 1 Analisi Swot.

[29] Catania, Urban renewal, Garden Bellini, Asse VI, FERS P.O. 2007/2013 available at: www.iessolutions.eu/progetti-altro/il-3d-giardino-bellini-di-catania.

[30] Messina, realization of a parcking, Asse VI, FERS Fondo Europeo Regionale P.O. 2007/2013.

[31] Barcellona Pozzo di Gotto (Messina), urban renewal, Asse VI, FERS Fondo Europeo Regionale P.O. 2007/2013.

[32] San Giovanni La Punta (Catania), construction of a service center, Asse VI, FERS Fondo Europeo Regionale P.O. 2007/2013.

[33] Valderice (Trapani), redevelopment intervention of the sports facility, Asse VI, FERS Fondo Europeo Regionale P.O. 2007/2013.

[34] Comune di Maletto (Catania), urban rewal, Asse VI, FERS Fondo Europeo Regionale P.O. 2007/2013.

[35] Comune di Mazzarino (Caltanissetta), restoration work Bartoli Building, Asse VI, FERS Fondo Europeo Regionale P.O. 2007/2013. 